\title{
Effects of the Temperature and the pH on the Main Protease of SARS-CoV-2: A Molecular Dynamics Simulation Study
}

\author{
Azadeh Kordzadeh ${ }^{1}$, Ahmad Ramazani Saadatabadi 1,*(i) \\ 1 Chemical and Petroleum Engineering Department, Sharif University of Technology, Tehran, Iran; \\ azadeh.kordzadeh@che.sharif.edu (A.K.); ramazani@sharif.edu (A.R.S.A.); \\ * Correspondence: ramazani@ sharif.edu (A.R.S.A.);
}

Scopus Author ID 7006466561

Received: 8.09.2021; Revised: 22.10.2021; Accepted: 26.10.2021; Published: 24.11.2021

\begin{abstract}
The novel coronavirus, recognized as COVID-19, is the cause of an infection outbreak in December 2019. The effect of temperature and $\mathrm{pH}$ changes on the main protease of SARS-CoV-2 were investigated using all-atom molecular dynamics simulation. The obtained results from the root mean square deviation (RMSD) and root mean square fluctuations (RMSF) analyses showed that at a constant temperature of $25^{\circ} \mathrm{C}$ and $\mathrm{pH}=5$, the conformational change of the main protease is more significant than that of $\mathrm{pH}=6$ and 7 . Also, by increasing temperature from $25^{\circ} \mathrm{C}$ to $55^{\circ} \mathrm{C}$ at constant $\mathrm{pH}=7$, a remarkable change in protein structure was observed. The radial probability of water molecules around the main protease was decreased by increasing temperature and decreasing $\mathrm{pH}$. The weakening of the binding energy between the main protease and water molecules due to the increasing temperature and decreasing $\mathrm{pH}$ has reduced the number of hydrogen bonds between the main protease and water molecules. Finding conditions that alter the conformation of the main protease could be fundamental because this change could affect the virus's functionality and its ability to impose illness.
\end{abstract}

Keywords: main protease of SARS-CoV-2; molecular dynamics simulation; temperature; $\mathrm{pH}$.

(C) 2021 by the authors. This article is an open-access article distributed under the terms and conditions of the Creative Commons Attribution (CC BY) license (https://creativecommons.org/licenses/by/4.0/).

\section{Introduction}

Novel coronavirus $(\mathrm{CoV})$, severe acute respiratory syndrome coronavirus 2 (SARSCoV-2), was first identified in December 2019 in Wuhan [1,2]. It was then gradually recognized as one of the worst known global pandemics of this century that caused 4871841 deaths worldwide until 14 October 2021 [3]. SARS-CoV-2 belongs to the Betacoronavirus family, which also contains SARS-CoV and Middle East respiratory syndrome CoV (MERS$\mathrm{CoV}$ ) [4]. This virus consists of a genetic material enveloped with a protein capsid appearing like a crown, which means "corona" in Latin [5]. The SARA-CoV-2 enters the human cells through the angiotensin-converting enzyme 2 (ACE2) receptor and could infect different organs such as the liver, pancreas, eyes, digestive system, renal system, and brain [6].

It is indicated that SARS-CoV-2 survived at $4^{\circ} \mathrm{C}$ but was quickly deactivated at elevated temperatures of $50^{\circ} \mathrm{C}$. It is shown that the SARS-CoV-2 has greater viability on smooth surfaces such as plastics and iron than paper, tissue, wood, or cloth. Surgical masks had detectable viruses even on the 7 th day $[7,8]$. Influenza virus is active at a temperature around $37^{\circ} \mathrm{C}$, whereas higher temperatures of $41^{\circ} \mathrm{C}$ result in viruses clumping on cell surfaces [9-11]. Similarly, the SARS-CoV is effective for 5 days at temperatures ranging between $22-25^{\circ} \mathrm{C}$, 
and $40-50 \%$ humidity was lost when the temperature was raised to $38{ }^{\circ} \mathrm{C}$ and $95 \%$ humidity [12]. Different temperature and $\mathrm{pH}$ conditions affect the structures of proteins. Rath et al. [13] by molecular dynamics showed that the spike protein of SARS-CoV-2 has an open conformation that enables receptor binding at lower temperatures. While increasing temperature to $40{ }^{\circ} \mathrm{C}$, a closed conformation of the motif was observed. At temperatures $>50$ ${ }^{\circ} \mathrm{C}$, the Spike is completely closed. The main proteinase is a crucial enzyme in the processing of the viral polyproteins and thus an attractive target for the discovery of drugs directed against SARS-CoV-2. A theoretical and experimental study demonstrated the significant $\mathrm{pH}-$ dependent conformational changes of the SARS main protease [14]. The crystal structure for the main protease of SARS-CoV-2, 3-chymotrypsin-like cysteine protease (3CLpro), is considerably similar to previously reported SARS-CoV. It is a dimeric protein, which consists of two asymmetric units designated as protomers. Each protomer has three domains, namely domain I (residues 8-101), domain II (residues 102-184), and domain III (residues 201-303). Domain III comprises five $\alpha$-helices and is linked with domain II through an extended loop region (residues 185-200). The 3CLpro has a Cys_145 and His_41 catalytic dyad, and the substrate-binding site is positioned in the cleft between domain I and II. These descriptions match with the previously reported protease enzyme of SARS-CoV [15-18]. A molecular dynamics simulation by Bzowka et al.[19] elucidated that despite a high sequence similarity between the main protease of SARS-CoV-2 and SARS-CoV, the active sites in both proteins show significant differences in both shape and size, indicating that repurposing SARS drugs for COVID-19 may be ineffective. The 3CLpro of SARS-CoV-2 is a vital drug target, and computer-aided drug design (CADD) is considered a fundamental and significant approach to discovering antiviral drug candidates [20-29].

Here, by using all-atom molecular dynamics (MD) simulations, we explore the dynamics of the main protease of SARS-CoV-2 at different temperatures and pHs. The conformational changes of the main protease by changing temperature and $\mathrm{pH}$ were investigated. The study will help us understand the nature of the virus but is also helpful in designing effective therapeutic strategies to overcome the pandemic.

\section{Materials and Methods}

\subsection{The Structural model.}

The main protease of SARS-CoV-2 with PDB ID 6LU7 was obtained from the protein data bank server [30]. The main protease charge at $\mathrm{pH}=7$ is -4 . At $\mathrm{pH}=6$ by protonation of HIS 64 , HIS 246, and HIS 80, the main protease charge became -1 . The main protease charge reached zero at $\mathrm{pH}=5$ by protonation of HIS 64, HIS 246, HIS 172, and HIS 80.

\subsection{Force field.}

The GROMACS 5.1.4 simulation package [31] was employed to perform all simulations. The visual molecular dynamics (VMD 1.9.1) [32] program was used for molecular visualization. The all-atom GROMOS54A7 force field was employed to calculate all bonded and nonbonded interactions [33]. The simple point charge [34] model was selected for water molecules. 


\subsection{MD simulation.}

The simulations were performed in the isothermal-isobaric ensemble (NPT ensemble). During the simulation, the temperature was kept constant using a Nose'-Hoover thermostat [35], and the pressure was kept constant at atmospheric pressure using the Parrinello-Rahman barostat [36] with semi-isotropic pressure coupling [37]. The time step was $2 \mathrm{fs}$, and the Linear Constraint Solver (LINCS algorithm) [38] was used to constrain all bonds. The particle mesh Ewald method with a cut-off radius of $1.2 \mathrm{~nm}$ was applied to calculate the long-range electrostatic interactions [39]. The Lennard-Jones potential was used to calculate the van der Waals (vdW) interaction with a cut-off radius of $1.2 \mathrm{~nm}$ as recommended [40]. The simulation box dimensions for each system were $\left(8 \times 8 \times 8 \mathrm{~nm}^{3}\right)$. The main protease at $\mathrm{pH}=5,6$ and 7 was simulated at a constant temperature of $25{ }^{\circ} \mathrm{C}$. Also, this simulation was performed at temperatures of $25^{\circ} \mathrm{C}, 35^{\circ} \mathrm{C}, 45^{\circ} \mathrm{C}$, and $55^{\circ} \mathrm{C}$ with constant $\mathrm{pH}=7$. The constant volume ensemble (NVT) was simulated for $10 \mathrm{~ns}$ to fix the simulation box temperature. The pressure was adjusted at atmospheric pressure in the NPT ensemble for $10 \mathrm{~ns}$. Then the MD step was performed for $30 \mathrm{~ns}$ for data collection, and the last $5 \mathrm{~ns}$ were used for analysis.

\section{Results and Discussion}

\subsection{Structural changes.}

Electrostatic and $\mathrm{vdW}$ interactions between the main protease and water molecules change the conformation of the main protease. The final conformations of the main protease at the end of simulation time are illustrated in Figure 1. The main protease's root means square deviation (RMSD) at $25^{\circ} \mathrm{Cand} \mathrm{pH}=5,6,7$ are compared in Figure 2 (a). The presented results in Figure 2 (a) reveal that the conformations of the main protease at $\mathrm{pH}=6$ and $\mathrm{pH}=7$ are similar while it has changed significantly at $\mathrm{pH}=5$. The effect of temperature at constant $\mathrm{pH}(\mathrm{pH}=7)$ on the RMSD of the main protease is presented in Figure 2(b) where demonstrates that the structural changes of the main protease at $55^{\circ} \mathrm{C}$ are remarkable than that of $25^{\circ} \mathrm{C}, 35^{\circ} \mathrm{C}$, and $45^{\circ} \mathrm{C}$. The conformational changes of the main protease could inactive the main function of the protein and disable SARS-CoV-2. It is demonstrated that the conformational changes of the main protease of SARS-CoV-2 are more sensible with temperature than the spike protein [13].

The root means square fluctuation (RMSF) of the main protease atoms is presented in Figure 3. The results of RMSF follow RMSD, which confirms that the conformation of the main protease has changed significantly at $\mathrm{pH}=5$ and a constant temperature of $25^{\circ} \mathrm{C}$. Also, Figure 3 (b) clarifies that the RMSF of the main protease at $55{ }^{\circ} \mathrm{C}$ is significantly different from $25^{\circ} \mathrm{C}, 35^{\circ} \mathrm{C}, 45^{\circ} \mathrm{C}$ at constant $\mathrm{pH}=7$, and fluctuations of atoms 2000 to 3000 are remarkable.

Changes in the radius of gyration of the main protease due to $\mathrm{pH}$ and temperature are shown in Figure 4. The presented results in Figure 4 (a) reveal that the radius of gyration of the main protease at $\mathrm{pH}=6$ is different from $\mathrm{pH}=5,7$. Also, with increasing temperature from $25^{\circ} \mathrm{C}$ to $55^{\circ} \mathrm{C}$, the main protease radius of gyration has increased from $2.21 \mathrm{~nm}$ to $2.27 \mathrm{~nm}$. The radius of gyration is a criterion for distributing amino acids around the center of mass of the main protease; therefore, the change in the radius of gyration confirms the change in protein conformation. 

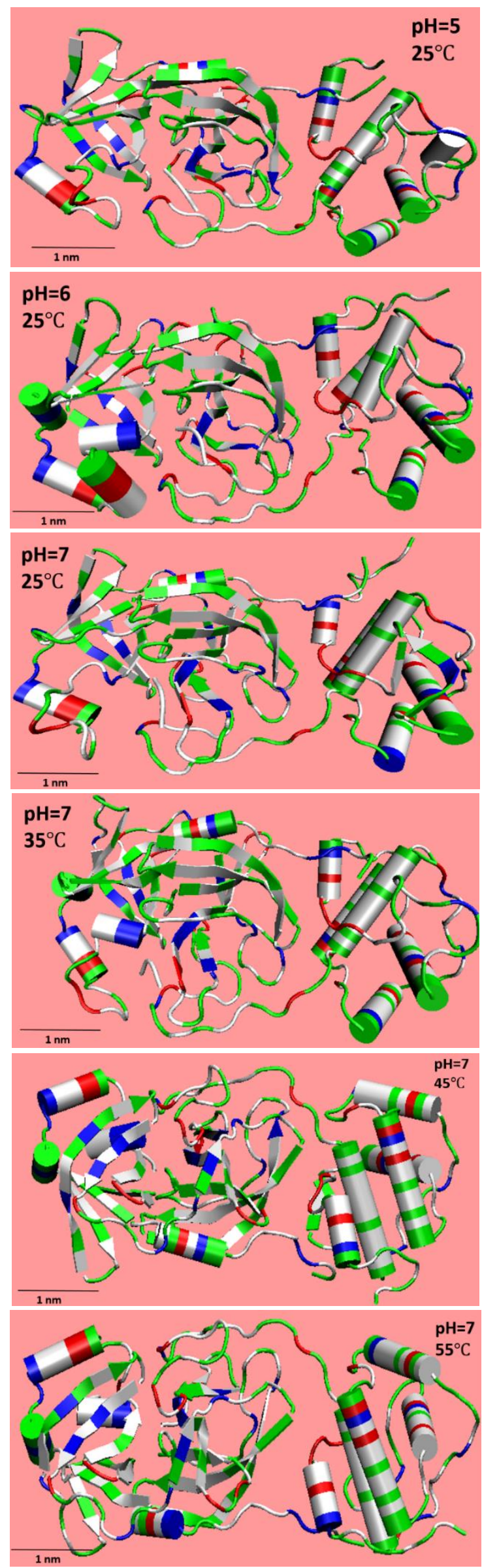

Figure 1. The snapshots of the main protease at the end of simulation time. The main protease is shown with white, green, red, and blue cartoon, representing nonpolar, polar, acidic, and basic amino acids. 

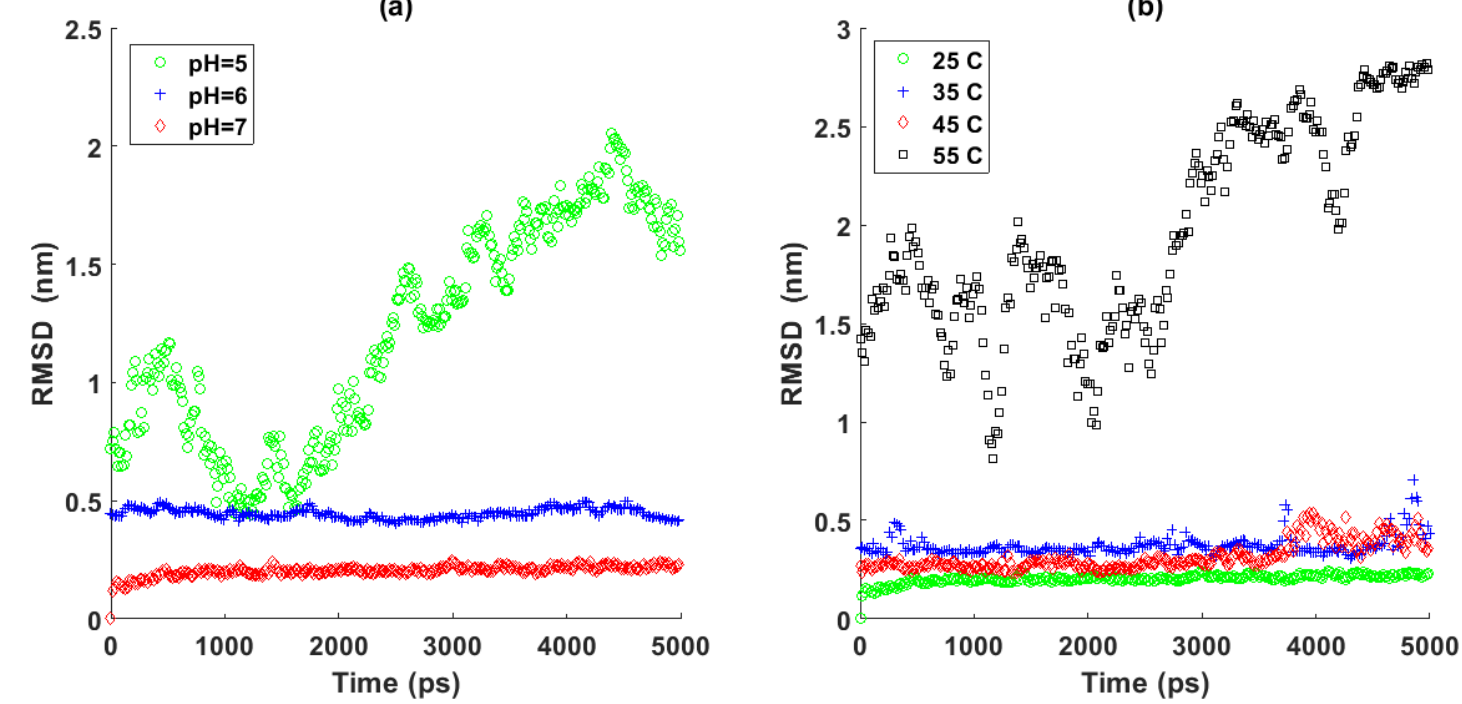

Figure 2. The root means square deviation (RMSD) of the main protease at (a) constant temperature of $25^{\circ} \mathrm{C}$ and $\mathrm{pH}=5,6,7$ (b) constant $\mathrm{pH}=7$ and temperatures of $25^{\circ} \mathrm{C}, 35^{\circ} \mathrm{C}, 45^{\circ} \mathrm{C}$ and $55^{\circ} \mathrm{C}$.
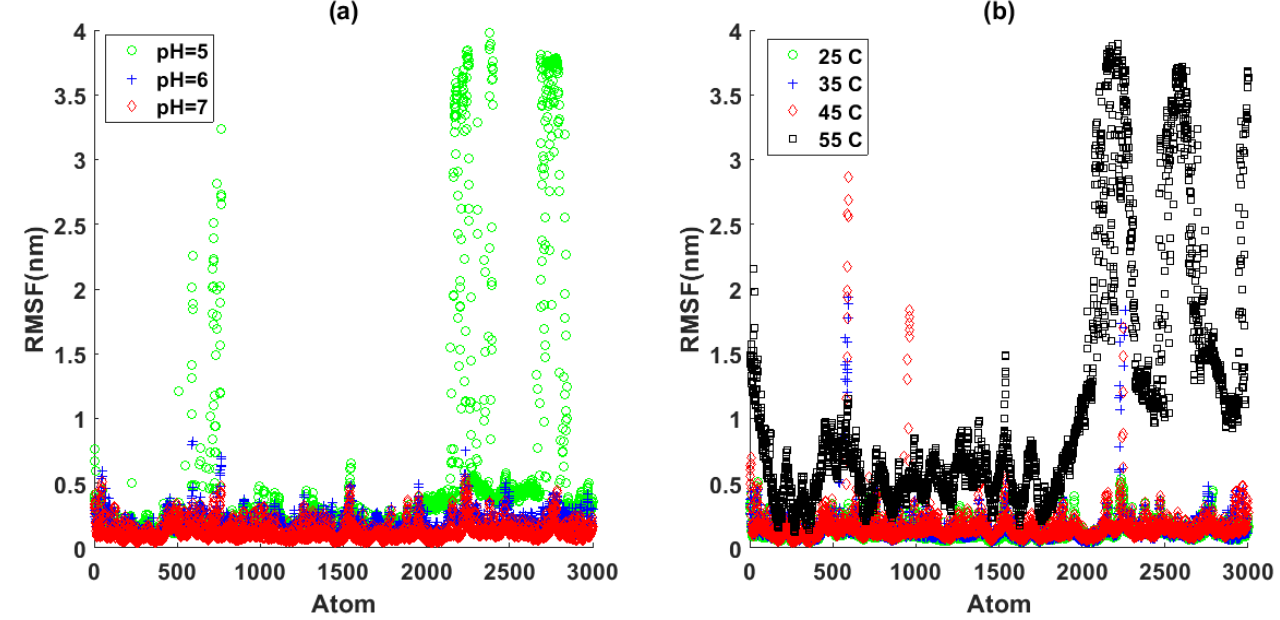

Figure 3. The root means square fluctuation (RMSF) of the main protease at (a) constant temperature of $25^{\circ} \mathrm{C}$ and $\mathrm{pH}=5,6,7$ (b) constant $\mathrm{pH}=7$ and temperatures of $25^{\circ} \mathrm{C}, 35^{\circ} \mathrm{C}, 45^{\circ} \mathrm{C}$ and $55^{\circ} \mathrm{C}$.

(a)

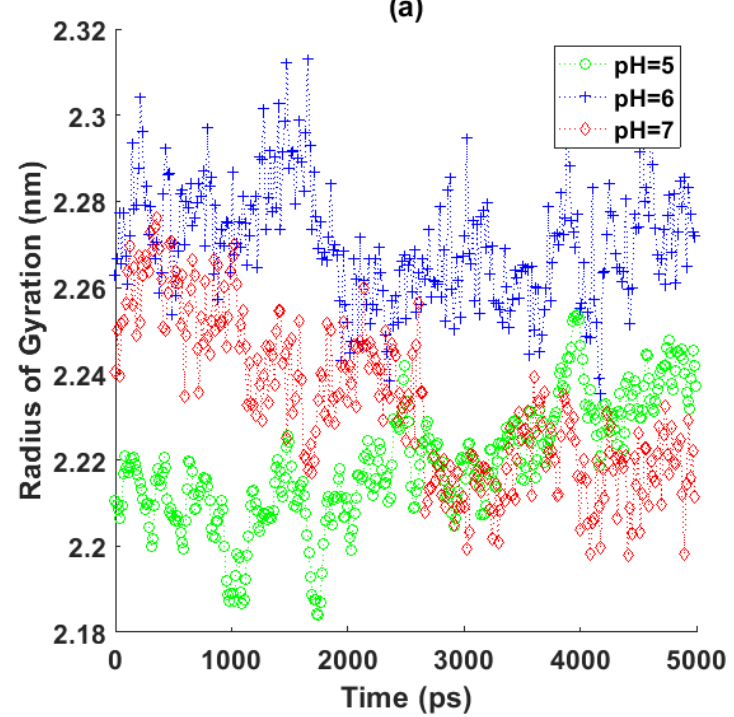

(b)

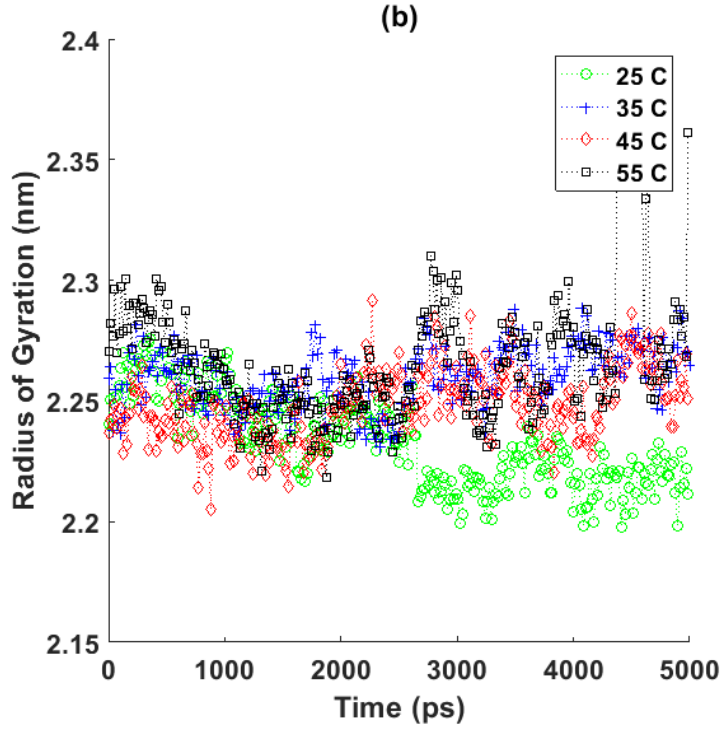

Figure 4. The radius of gyration of the main protease at (a) constant temperature of $25^{\circ} \mathrm{C}$ and $\mathrm{pH}=5,6,7$ (b) constant $\mathrm{pH}=7$ and temperatures of $25^{\circ} \mathrm{C}, 35^{\circ} \mathrm{C}, 45^{\circ} \mathrm{C}$ and $55^{\circ} \mathrm{C}$. 


\subsection{Hydrophilicity.}

The number of hydrogen bonds between the main protease and water molecules and the solvent-accessible surface area (SASA) of the main protease are reported in Table 1. By increment of temperature from $25^{\circ} \mathrm{C}$ to $55^{\circ} \mathrm{C}$, the number of hydrogen bonds between the main protease and water molecules decreased from 552 to 531, decreasing SASA with increment in temperature was observed. This change in hydrophilicity of the main protease with $\mathrm{pH}$ and temperate is due to conformational changes that RMSD and RMSF confirmed in section 3.1. The radial probability of finding water molecules around the main protease is illustrated in Figure 5. At a radius of $4 \mathrm{~nm}$ from the center of mass of the main protease, the radial probability of finding water molecules approaches a constant value. Two peaks in Figure 4 (a) and (b) demonstrate two layers of water molecules around the main protease. The obtained results in Figure 5 (a) reveal that by decreasing $\mathrm{pH}$ from 7 to 5, the height of the second peak or the probability of finding water molecules has decreased, following a decreasing number of hydrogen bonds between the main protease and water molecules. Also, by increasing temperature from $25^{\circ} \mathrm{C}$ to $55^{\circ} \mathrm{C}$ the height of the second peak in Figure 5 (b) has decreased.

Table 1. Number of hydrogen bonds (NHB) between the main protease and water and solvent accessible surface area (SASA) of the main protease in different simulated systems.

\begin{tabular}{c|c|c|c}
$\mathbf{p H}$ & Temperature $\left({ }^{\circ} \mathrm{C}\right)$ & $\mathbf{N H B}$ & $\mathbf{S A S A}\left(\mathbf{n m}^{\mathbf{2}}\right)$ \\
\hline 5 & 25 & 541 & 150 \\
\hline 6 & 25 & 553 & 152 \\
\hline 7 & 25 & 552 & 153 \\
\hline 7 & 35 & 552 & 153 \\
\hline 7 & 45 & 536 & 152 \\
\hline 7 & 55 & 531 & 150
\end{tabular}
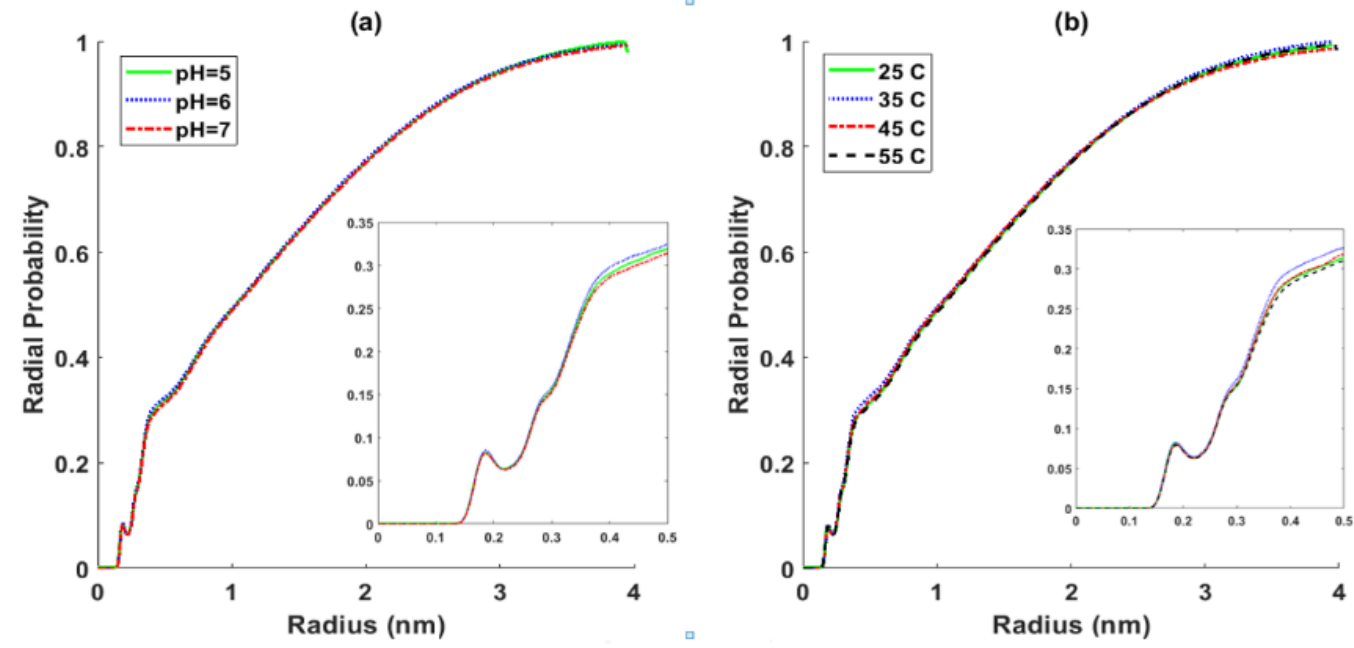

Figure 5. The radial probability of water molecules around the main protease (a) constant temperature of $25^{\circ} \mathrm{C}$ and $\mathrm{pH}=5,6,7$ (b) constant $\mathrm{pH}=7$ and temperatures of $25^{\circ} \mathrm{C}, 35^{\circ} \mathrm{C}, 45^{\circ} \mathrm{C}$ and $55^{\circ} \mathrm{C}$.

\subsection{Interaction potential.}

The binding energy between the main protease and water molecules is due to LennardJones and electrostatic potentials, which are shown in Figures 6 and 7. Negative values of LJ potential describe attraction potential between the main protease and water molecules. By increasing temperature from $25^{\circ} \mathrm{C}$ to $55^{\circ} \mathrm{C}$, the $\mathrm{LJ}$ potentials decreased from $-920.3144 \mathrm{~kJ} / \mathrm{mol}$ to $-837.1359 \mathrm{~kJ} / \mathrm{mol}$, and electrostatic potentials decreased from $-18816 \mathrm{~kJ} / \mathrm{mol}$ to - 
$18128 \mathrm{~kJ} / \mathrm{mol}$. By decreasing $\mathrm{pH}$ from 7 to 5 the electrostatic potentials between the main protease and water decreased from $-18816 \mathrm{~kJ} / \mathrm{mol}$ to $-18454 \mathrm{~kJ} / \mathrm{mol}$ due to the changing main protease charge from -4 to zero. Changing LJ and electrostatic potentials have altered the conformation and hydrophilicity of the main protease that were discussed in sections 3.1 and 3.2 .

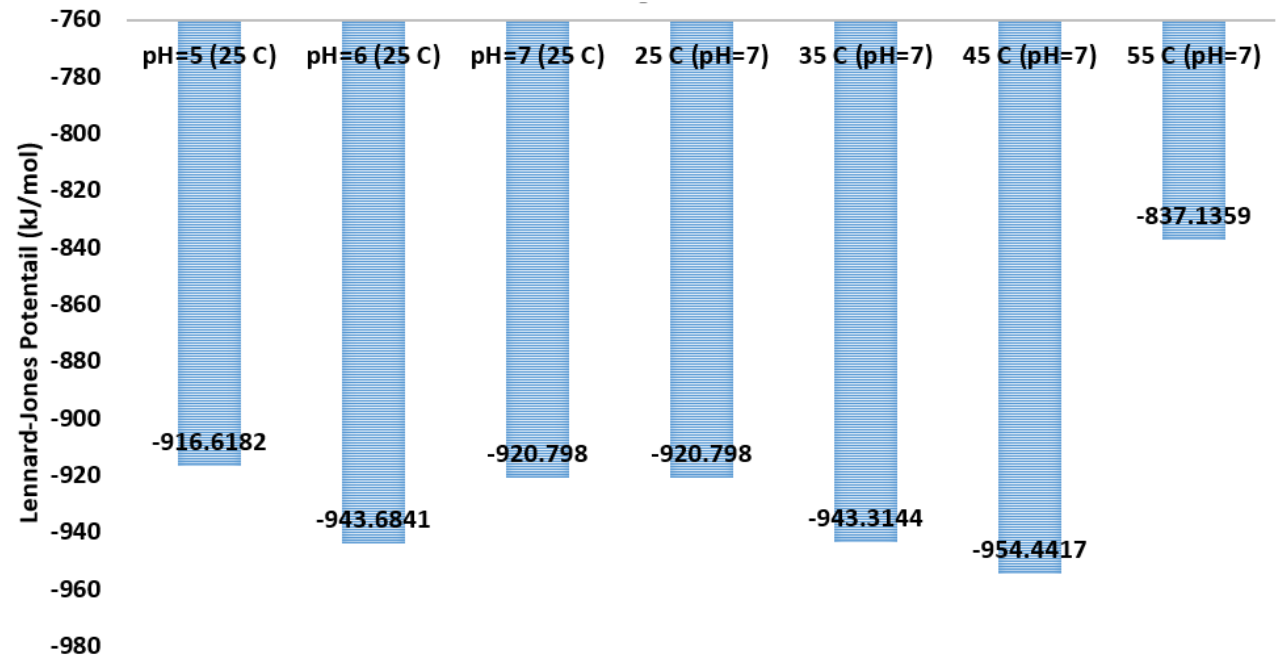

Figure 6. The Lennard-Jones potential between the main protease and water at a constant temperature of $25^{\circ} \mathrm{C}$ and $\mathrm{pH}=5,6,7$ and also at constant $\mathrm{pH}=7$ and temperatures of $25^{\circ} \mathrm{C}, 35^{\circ} \mathrm{C}, 45^{\circ} \mathrm{C}$ and $55^{\circ} \mathrm{C}$.

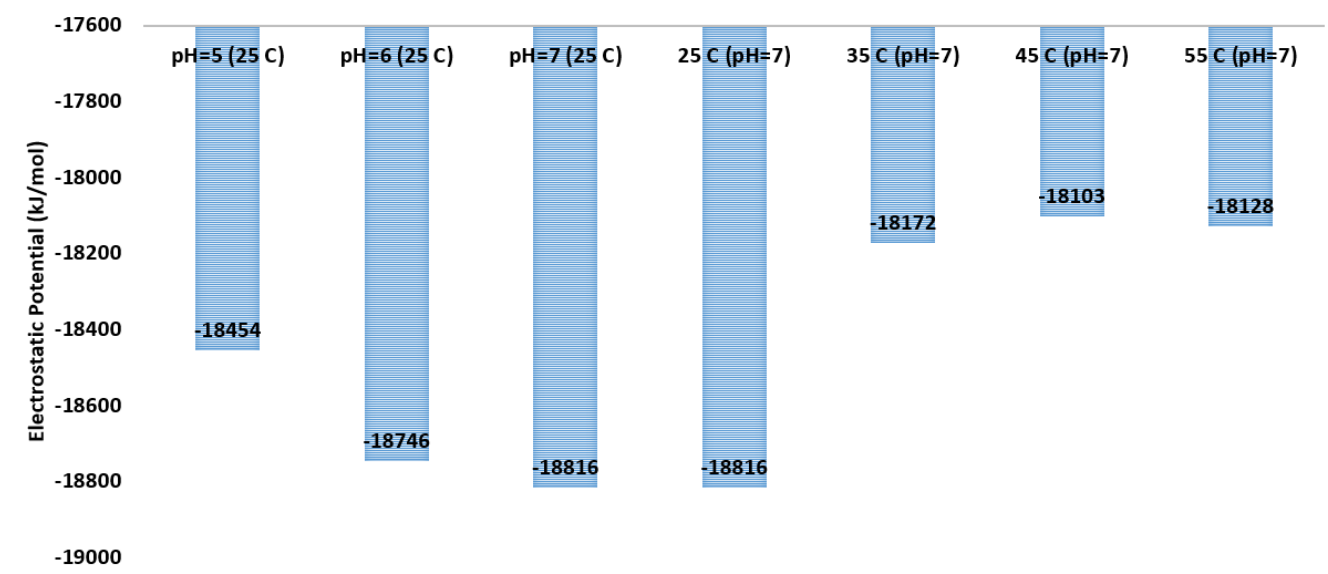

Figure 7. The electrostatic potential between the main protease and water at a constant temperature of $25^{\circ} \mathrm{C}$ and $\mathrm{pH}=5,6,7$ and also at constant $\mathrm{pH}=7$ and temperatures of $25^{\circ} \mathrm{C}, 35^{\circ} \mathrm{C}, 45^{\circ} \mathrm{C}$ and $55^{\circ} \mathrm{C}$.

\section{Conclusions}

The effects of temperature and $\mathrm{pH}$ changes on the main protease of SARS-CoV-2 were investigated using molecular dynamics simulation. At a constant temperature of $25^{\circ} \mathrm{C}$, the $\mathrm{pH}$ changed from 7 to 5 , and also, at constant $\mathrm{pH}=7$, the temperature was increased from $25^{\circ} \mathrm{C}$ to $55^{\circ} \mathrm{C}$. By changing $\mathrm{pH}$ from 7 to 5 , the main protease surface charge was changed from -4 to zero due to the protonation of histidine amino acids (HIS). The conformational changes of the main protease were assessed by the root mean square deviation (RMSD), the root mean square fluctuation (RMSF), and the radius of gyration analyses. The conformational changes of the main protease at the temperature of $25^{\circ} \mathrm{C}$ and $\mathrm{pH}=5$ and at the temperature of $55^{\circ} \mathrm{C}$ and $\mathrm{pH}=7$ are significant. The hydrophilicity of the main protease was evaluated by solvent accessible surface area analysis and the number of hydrogen bonds with water molecules. It is shown that by increasing temperature from $25^{\circ} \mathrm{C}$ to $55^{\circ} \mathrm{C}$ and decreasing $\mathrm{pH}$ from 7 to 5 , the hydrophilicity decrement was observed, confirming the main protease's conformational changes. Also, 
decreasing $\mathrm{pH}$ and increasing the temperature have been reduced the radial probability of water molecules around the main protease. The calculated Lennard-Jones and electrostatic potentials indicated that decreasing $\mathrm{pH}$ and the increasing temperature had weakened the binding energy between the main protease and water molecules. It seems that the structural changes of the main protease could disable its functionality and behavior in the water medium. Therefore, finding the conditions that change the main protease's conformation could help researchers stop virus activity and pandemics.

\section{Funding}

This research received no external funding.

\section{Acknowledgments}

This research has no acknowledgment.

\section{Conflicts of Interest}

The authors declare no conflict of interest.

\section{References}

1. Bogoch, I.I.; Watts, A.; Thomas-Bachli, A.; Huber, C.; Kraemer, M.U.G.; Khan, K. Pneumonia of unknown aetiology in Wuhan, China: potential for international spread via commercial air travel. Journal of Travel Medicine 2020, 27, https://doi.org/10.1093/jtm/taaa008.

2. Helmy, Y.A.; Fawzy, M.; Elaswad, A.; Sobieh, A.; Kenney, S.P.; Shehata, A.A. The COVID-19 Pandemic: A Comprehensive Review of Taxonomy, Genetics, Epidemiology, Diagnosis, Treatment, and Control. Journal of Clinical Medicine 2020, 9, https://doi.org/10.3390/jcm9041225.

3. Available online: https://covid19. who.int/ (accessed on 14 October 2021).

4. Woo, P.C.Y.; Huang, Y.; Lau, S.K.P.; Yuen, K.-Y. Coronavirus Genomics and Bioinformatics Analysis. Viruses 2010, 2, 1804-1820, https://doi.org/10.3390/v2081803.

5. Pene, F.; Merlat, A.; Vabret, A.; Rozenberg, F.; Buzyn, A.; Dreyfus, F.; Cariou, A.; Freymuth, F.; Lebon, P. Coronavirus 229E-Related Pneumonia in Immunocompromised Patients. Clinical Infectious Diseases 2003, 37, 929-932, https://doi.org/10.1086/377612.

6. Gordon, D.E.; Jang, G.M.; Bouhaddou, M.; Xu, J.; Obernier, K.; White, K.M.; O’Meara, M.J.; Rezelj, V.V.; Guo, J.Z.; Swaney, D.L.; Tummino, T.A.; Hüttenhain, R.; Kaake, R.M.; Richards, A.L.; Tutuncuoglu, B.; Foussard, H.; Batra, J.; Haas, K.; Modak, M.; Kim, M.; Haas, P.; Polacco, B.J.; Braberg, H.; Fabius, J.M.; Eckhardt, M.; Soucheray, M.; Bennett, M.J.; Cakir, M.; McGregor, M.J.; Li, Q.; Meyer, B.; Roesch, F.; Vallet, T.; Mac Kain, A.; Miorin, L.; Moreno, E.; Naing, Z.Z.C.; Zhou, Y.; Peng, S.; Shi, Y.; Zhang, Z.; Shen, W.; Kirby, I.T.; Melnyk, J.E.; Chorba, J.S.; Lou, K.; Dai, S.A.; Barrio-Hernandez, I.; Memon, D.; HernandezArmenta, C.; Lyu, J.; Mathy, C.J.P.; Perica, T.; Pilla, K.B.; Ganesan, S.J.; Saltzberg, D.J.; Rakesh, R.; Liu, X.; Rosenthal, S.B.; Calviello, L.; Venkataramanan, S.; Liboy-Lugo, J.; Lin, Y.; Huang, X.-P.; Liu, Y.; Wankowicz, S.A.; Bohn, M.; Safari, M.; Ugur, F.S.; Koh, C.; Savar, N.S.; Tran, Q.D.; Shengjuler, D.; Fletcher, S.J.; O’Neal, M.C.; Cai, Y.; Chang, J.C.J.; Broadhurst, D.J.; Klippsten, S.; Sharp, P.P.; Wenzell, N.A.; Kuzuoglu-Ozturk, D.; Wang, H.-Y.; Trenker, R.; Young, J.M.; Cavero, D.A.; Hiatt, J.; Roth, T.L.; Rathore, U.; Subramanian, A.; Noack, J.; Hubert, M.; Stroud, R.M.; Frankel, A.D.; Rosenberg, O.S.; Verba, K.A.; Agard, D.A.; Ott, M.; Emerman, M.; Jura, N.; von Zastrow, M.; Verdin, E.; Ashworth, A.; Schwartz, O.; d'Enfert, C.; Mukherjee, S.; Jacobson, M.; Malik, H.S.; Fujimori, D.G.; Ideker, T.; Craik, C.S.; Floor, S.N.; Fraser, J.S.; Gross, J.D.; Sali, A.; Roth, B.L.; Ruggero, D.; Taunton, J.; Kortemme, T.; Beltrao, P.; Vignuzzi, M.; García-Sastre, A.; Shokat, K.M.; Shoichet, B.K.; Krogan, N.J. A SARS-CoV-2 protein interaction map reveals targets for drug repurposing. Nature 2020, 583, 459-468, https://doi.org/10.1038/s41586-020-2286-9.

7. Casanova Lisa, M.; Jeon, S.; Rutala William, A.; Weber David, J.; Sobsey Mark, D. Effects of Air Temperature and Relative Humidity on Coronavirus Survival on Surfaces. Applied and Environmental Microbiology 2010, 76, 2712-2717, https://doi.org/10.1128/AEM.02291-09.

8. van Doremalen, N.; Bushmaker, T.; Morris, D.H.; Holbrook, M.G.; Gamble, A.; Williamson, B.N.; Tamin, A.; Harcourt, J.L.; Thornburg, N.J.; Gerber, S.I.; Lloyd-Smith, J.O.; de Wit, E.; Munster, V.J. Aerosol and 
Surface Stability of SARS-CoV-2 as Compared with SARS-CoV-1. New England Journal of Medicine 2020, 382, 1564-1567, https://doi.org/10.1056/NEJMc2004973.

9. Ishida, Y.; Hiraki, A.; Hirayama, E.; Koga, Y.; Kim, J. Temperature-sensitive viral infection: inhibition of hemagglutinating virus of Japan (Sendai virus) infection at 41 degrees. Intervirology 2002, 45, 125-135, https://doi.org/10.1159/000065865.

10. Lowen, A.; Steel, J. Roles of Humidity and Temperature in Shaping Influenza Seasonality. Journal of virology 2014, 88, https://doi.org/10.1128/JVI.03544-13.

11. Pelletier, I.; Rousset, D.; Enouf, V.; Colbere-Garapin, F.; van der Werf, S.; Naffakh, N.J.E. Highly heterogeneous temperature sensitivity of 2009 pandemic influenza A (H1N1) viral isolates, northern France. Euro surveillance : bulletin Europeen sur les maladies transmissibles = European communicable disease bulletin 2011, 16.

12. Chan, K.H.; Peiris, J.S.M.; Lam, S.Y.; Poon, L.L.M.; Yuen, K.Y.; Seto, W.H. The Effects of Temperature and Relative Humidity on the Viability of the SARS Coronavirus. Advances in Virology 2011, 2011, https://doi.org/10.1155/2011/734690.

13. Rath, S.L.; Kumar, K. Investigation of the Effect of Temperature on the Structure of SARS-CoV-2 Spike Protein by Molecular Dynamics Simulations. Frontiers in Molecular Biosciences 2020, 7 , https://doi.org/10.3389/fmolb.2020.583523.

14. Tan, J.; Verschueren, K.H.G.; Anand, K.; Shen, J.; Yang, M.; Xu, Y.; Rao, Z.; Bigalke, J.; Heisen, B.; Mesters, J.R.; Chen, K.; Shen, X.; Jiang, H.; Hilgenfeld, R. pH-dependent Conformational Flexibility of the SARS-CoV Main Proteinase (Mpro) Dimer: Molecular Dynamics Simulations and Multiple X-ray Structure Analyses. Journal of Molecular Biology 2005, 354, 25-40, https://doi.org/10.1016/j.jmb.2005.09.012.

15. Anand, K.; Palm, G.J.; Mesters, J.R.; Siddell, S.G.; Ziebuhr, J.; Hilgenfeld, R. Structure of coronavirus main proteinase reveals combination of a chymotrypsin fold with an extra alpha-helical domain. The EMBO journal 2002, 21, 3213-3224, https://doi.org/10.1093/emboj/cdf327.

16. Mukherjee, P.; Shah, F.; Desai, P.; Avery, M. Inhibitors of SARS-3CLpro: virtual screening, biological evaluation, and molecular dynamics simulation studies. Journal of chemical information and modeling 2011, 51, 1376-1392, https://doi.org/10.1021/ci1004916.

17. Ren, Z.; Liming, Y.; Zhang, N.; Guo, Y.; Yang, C.; Lou, Z.; Rao, Z. The newly emerged SARS-Like coronavirus HCoV-EMC also has an "Achilles' heel": Current effective inhibitor targeting a 3C-like protease. Protein \& cell 2013, 4, 248-250, https://doi.org/10.1007/s13238-013-2841-3.

18. Yang, H.; Yang, M.; Ding, Y.; Liu, Y.; Lou, Z.; Zhou, Z.; Sun, L.; Mo, L.; Ye, S.; Pang, H.; Gao, G.F.; Anand, K.; Bartlam, M.; Hilgenfeld, R.; Rao, Z. The crystal structures of severe acute respiratory syndrome virus main protease and its complex with an inhibitor. Proceedings of the National Academy of Sciences of the United States of America 2003, 100, 13190-13195, https://doi.org/10.1073/pnas.1835675100.

19. Bzówka, M.; Mitusińska, K.; Raczyńska, A.; Samol, A.; Tuszynski, J.; Gora, A. Molecular Dynamics Simulations Indicate the COVID-19 Mpro Is Not a Viable Target for Small-Molecule Inhibitors Design. 2020.

20. Dayer, M.R.; Taleb-Gassabi, S.; Dayer, M.S. Lopinavir; A Potent Drug against Coronavirus Infection: Insight from Molecular Docking Study. Archives of Clinical Infectious Diseases 2017, 12, https://doi.org/10.5812/archcid.13823.

21. Hagar, M.; Ahmed, H.A.; Aljohani, G.; Alhaddad, O.A. Investigation of Some Antiviral N-Heterocycles as COVID 19 Drug: Molecular Docking and DFT Calculations. Int J Mol Sci 2020, 21, https://doi.org/10.3390/ijms21113922.

22. Joshi, T.; Joshi, T.; Sharma, P.; Mathpal, S.; Pundir, H.; Bhatt, V.; Chandra, S. In silico screening of natural compounds against COVID-19 by targeting Mpro and ACE2 using molecular docking. European review for medical and pharmacological sciences $24,25,4536$, https://doi.org/10.26355/eurrev_202004_21036.

23. Khaerunnisa, S.; Kurniawan, H.; Awaluddin, R.; Suhartati, S.; Soetjipto, S. Potential Inhibitor of COVID-19 Main Protease (Mpro) From Several Medicinal Plant Compounds by Molecular Docking Study 2020; https://doi.org/10.20944/preprints202003.0226.v1.

24. Kumar, Y.; Singh, H.; Patel, C.N. In silico prediction of potential inhibitors for the main protease of SARSCoV-2 using molecular docking and dynamics simulation based drug-repurposing. Journal of Infection and Public Health 2020, 13, 1210-1223, https://doi.org/10.1016/j.jiph.2020.06.016.

25. Narkhede, R.R.; Cheke, R.S.; Ambhore, J.P.; Shinde, S.D.J.E.J.o.M. The molecular docking study of potential drug candidates showing anti-COVID-19 activity by exploring of therapeutic targets of SARS-CoVOncology 2020, 4, 185-195. https://doi.org/10.14744/ejmo.2020.31503.

26. Shaghaghi, N. Molecular docking study of novel COVID-19 protease with low risk terpenoides compounds of plants. Chemrxiv $\mathbf{2 0 2 0 .}$

27. Singh, S.; Florez, H. Coronavirus disease 2019 drug discovery through molecular docking. F1000Res 2020, 9, 502-502, https://doi.org/10.12688/f1000research.24218.1.

28. Yu, J.W.; Wang, L.; Bao, L.D. Exploring the active compounds of traditional Mongolian medicine in intervention of novel coronavirus (COVID-19) based on molecular docking method. J Funct Foods 2020, 71, 104016, https://doi.org/10.1016/j.jff.2020.104016. 
29. Yu, R.; Chen, L.; Lan, R.; Shen, R.; Li, P. Computational screening of antagonists against the SARS-CoV-2 (COVID-19) coronavirus by molecular docking. Int $J$ Antimicrob Agents 2020, 56, https://doi.org/10.1016/j.ijantimicag.2020.106012.

30. Burley, S.K.; Berman, H.M.; Bhikadiya, C.; Bi, C.; Chen, L.; Di Costanzo, L.; Christie, C.; Dalenberg, K.; Duarte, J.M.; Dutta, S.; Feng, Z.; Ghosh, S.; Goodsell, D.S.; Green, R.K.; Guranovic, V.; Guzenko, D.; Hudson, B.P.; Kalro, T.; Liang, Y.; Lowe, R.; Namkoong, H.; Peisach, E.; Periskova, I.; Prlic, A.; Randle, C.; Rose, A.; Rose, P.; Sala, R.; Sekharan, M.; Shao, C.; Tan, L.; Tao, Y.P.; Valasatava, Y.; Voigt, M.; Westbrook, J.; Woo, J.; Yang, H.; Young, J.; Zhuravleva, M.; Zardecki, C. RCSB Protein Data Bank: biological macromolecular structures enabling research and education in fundamental biology, biomedicine, biotechnology and energy. Nucleic acids research 2019, 47, D464-D474, https://doi.org/10.1093/nar/gky1004.

31. Van Der Spoel, D.; Lindahl, E.; Hess, B.; Groenhof, G.; Mark, A.E.; Berendsen, H.J. GROMACS: fast, flexible, and free. J Comput Chem 2005, 26, 1701-1718, https://doi.org/10.1002/jcc.20291.

32. Humphrey, W.; Dalke, A.; Schulten, K. VMD: Visual molecular dynamics. Journal of Molecular Graphics 1996, 14, 33-38, https://doi.org/10.1016/0263-7855(96)00018-5.

33. Schmid, N.; Eichenberger, A.P.; Choutko, A.; Riniker, S.; Winger, M.; Mark, A.E.; van Gunsteren, W.F. Definition and testing of the GROMOS force-field versions 54A7 and 54B7. European Biophysics Journal 2011, 40, 843-856, https://doi.org/10.1007/s00249-011-0700-9.

34. Berendsen, H.J.; Postma, J.P.; van Gunsteren, W.F.; Hermans, J. Interaction models for water in relation to protein hydration. In: Intermolecular forces. Springer: 1981; pp. 331-342, https://doi.org/10.1007/978-94015-7658-1_21.

35. Bussi, G.; Donadio, D.; Parrinello, M. Canonical sampling through velocity rescaling. The Journal of Chemical Physics 2007, 126, https://doi.org/10.1063/1.2408420.

36. Berendsen, H.J.C.; Postma, J.P.M.; van Gunsteren, W.F.; DiNola, A.; Haak, J.R. Molecular dynamics with coupling to an external bath. The Journal of Chemical Physics 1984, 81, 3684-3690, https://doi.org/10.1063/1.448118.

37. Yousefpour, A.; Amjad Iranagh, S.; Nademi, Y.; Modarress, H. Molecular dynamics simulation of nonsteroidal antiinflammatory drugs, naproxen and relafen, in a lipid bilayer membrane. International Journal of Quantum Chemistry 2013, 113, 1919-1930, https://doi.org/10.1002/qua.24415.

38. Zheng, H.-D.; Wu, F.-D.; Wang, B.-Y.; Wu, Y.-X. Molecular dynamics simulation on the interfacial features of phenol extraction by TBP/dodecane in water. Computational and Theoretical Chemistry 2011, 970, 66-72, https://doi.org/10.1016/j.comptc.2011.05.028.

39. Darden, T.; York, D.; Pedersen, L. Particle mesh Ewald: An N·log(N) method for Ewald sums in large systems. The Journal of Chemical Physics 1993, 98, 10089-10092, https://doi.org/10.1063/1.464397.

40. Berendsen, H.J.C.; van der Spoel, D.; van Drunen, R. GROMACS: A message-passing parallel molecular dynamics implementation. Computer Physics Communications 1995, 91, 43-56, https://doi.org/10.1016/0010-4655(95)00042-E. 